\author{
A.T. Ordabaeva ${ }^{1}$, Zh.S. Akhmetkarimova ${ }^{1}$, M.G. Meiramov ${ }^{1}$, \\ V.A. Khrupov ${ }^{1}$, Zh.H. Muldakhmetov ${ }^{1}$, A.M. Dusekenov ${ }^{1}$, Ma Feng Yun ${ }^{2}$ \\ ${ }^{l}$ Institute of Organic Synthesis and Coal Chemistry of the Republic of Kazakhstan, Karaganda, Kazakhstan; \\ ${ }^{2}$ Xinjiang University, China \\ (E-mail:aigul_serik_kz@mail.ru)
}

\title{
Kinetics and thermodynamics of the process of hydrodesulfurization of Shubarkol coal hydrogenate
}

\begin{abstract}
When processing coals and oils containing sulfur compounds, the resulting fuel components do not meet the requirements of the State standards for sulfur content. Sulfur affects negatively the quality of the target product and makes processing difficult, therefore hydrodesulfurization of coal hydrogenates and oils is an important stage before further processing. Sulfur compounds are very harmful impurities for liquid products (hydrocarbons). They are toxic, give an unpleasant smell to liquid products, affect detrimentally the antiknock properties of gasolines, promote resin formation in internal combustion engines and, most importantly, cause corrosion of metals. Therefore, the presence of these substances is extremely undesirable and unacceptable. There has been researched the process of hydrodesulphurization of hydrogenates of the coal from Shubarkol Deposit in the presence of catalyst of pyrite and natural zeolite. Using the method of equilibrium-and-kinetic analysis there have been calculated the rates of the process of hydrodesulphurization of liquid products and Gibbs energy that are necessary for improvement of process-dependent parameters of hydrofining of liquid products of hydrogenation. It is indicated that the optimum time of the process of hydrodesulphurization is $15-25$ minutes. The content of sulfur in the fraction under $200^{\circ} \mathrm{C}$ is 0.043 per cent and in the fraction of 200 $300{ }^{\circ} \mathrm{C}$ is 0.065 per cent and that indicates a high degree of hydrofining of hydrogenate in the presence of the above catalyst. A high value of $\Delta G$ (in absolute value) indicates a high thermodynamic probability of hydrodesulfurization process in the given temperature range. These data are necessary for the development of recommendations for determining the optimal conditions for the process.
\end{abstract}

Keywords: hydrodesulfurization, hydrogenizat, kinetic analysis equilibrium.

\section{Introduction}

The Republic of Kazakhstan possesses enormous reserves of energy resources. In our country there are deposits of high-viscosity index oil (heavy oil) and coal that can be the sources for production of synthetic motor fuel and boiler fuel. In recent years there have considerably decreased the volumes of oil extraction and there is expected the deceleration in increase of the developed reserves of fossil fuels comparing with the rates of extraction. Extraction of oil in distant and hard-to-reach regions becomes so expensive that the production of synthetic oil out of coal in many cases is considered to be a competitive process as compared with the oil extraction. Therefore there arises a practical importance of producing fuel and chemical products out of coal and heavy oils that can be considered as one of the prospective lines in the energy sector and petrochemical industry of the nearest future. The process of direct hydrogenation of coal, heavy oils, petroleum bitumens and the products of coal liquefaction is one of the effective methods.

However, it should be noted that the fuel components produced as result of processing coals and oils that contain sulphur compounds do not meet the requirements of the State Standards as to sulphur content. Sulphur negatively affects the quality of the target product and complicates the processing, therefore hydrodesulphurization of coal hydrogenates and oils is a very important stage prior their further processing.

As is known, sulphur compounds are a very detrimental admixture for liquid products (hydrocarbons). They are toxic, impart an unpleasant odor to the liquid products, detrimentally effect the antiknock qualities of benzines, conduce to tar formation in internal-combustion engines and, what is most important, lead to corrosion of metals. Therefore the presence of these substances is extremely undesirable and inadmissible. The issues of refining sulphur oil-products by the method of hydrogenation without a considerable decomposition of hydrocarbons have been considered by many researchers. In the direction there worked B.L. Moldavsky, V.N. Pokorsky, K.P. Lavrovsky and P.V. Puchkov, A.V. Agafonov, et al. Most of their works are devoted to refining oil-products that are light as to their fraction content with the purpose of producing benzene and tractor kerosenes.

Previously there were conducted researches of hydrodesulfurization ability of Y-type zeolite that contained various admixtures. It was defined that zeolite catalysts that contain cobalt, nickel and rare-earth forms of Y-type zeolite possess a high hydrodesulfurization ability [1]. 
For hydrofining of oil-products there are mostly used aluminum-nickel-molybdenum (ANM) catalysts. However, zeolite-containing ANM catalysts are becoming more wide-spread; they are notable for a high activity in the processes of hydrofining [2-5]. Introduction of Y-zeolite into ANM-composition, besides the increase in activity of the catalyst, increased the efficiency of raw-materials plants (by 10-15 per cent), reduced the temperature of hydrofining (by 288-293 K) and extended the cycle length and general service period of catalysts. However, the role of zeolite in improvement of catalytic, operational and regeneration qualities of the catalysts of hydrofining is still not explored enough [4].

Therefore the aim of this work is to define kinetic and thermodynamic parameters of the process of hydrodesulphurization of the coal hydrogenate in the presence of the catalyst of pyrite and natural zeolite with the usage of equilibrium-and-kinetic analysis (EKA) method.

\section{Experimental part}

In the course of the work there was performed the definition of kinetic and thermodynamic parameters of the process of hydrodesulphurization with the usage of EKA method that has been worked out by Professor V.P. Malyshev [5].

The object of the research was hydrogenate of the coal from Shubarkol Deposit with the following physical and chemical characteristics (mass per cent): $\mathrm{A}-2.8-3.7$; $\mathrm{S}-0.4-0.49$; $\mathrm{V}-45.0-45.8$; $\mathrm{C}-$ 76.99; $\mathrm{H}-5.35$.

As the catalyst of the process of hydrodesulphurization of hydrogenate of Shubarkol coal there was used a mixture of pyrite and natural zeolite ( 60 per cent of pyrite and 40 per cent of zeolite).

The experiments on hydrodesulphurization of liquid products (hydrogenate) were performed in the rotary autoclave (with the volume of 0.021 ). The autoclave was loaded with hydrogenate, then there was added a calculated amount of catalyst ( 5 per cent of hydrogenate). The autoclave was closed, blown through with hydrogen and excessive (initial) pressure of hydrogen $(2 \mathrm{MPa})$ was created. The mixture was heated up to the necessary temperature with the rate of $278 \mathrm{~K}$ per min. and kept for the defined period of time under the temperature of $703 \mathrm{~K}$. After cooling of the autoclave up to the ambient temperature the resulted liquid products were separated and there was performed distillation in accordance with the State Standard 2177-48 [6]. In the resulted fractions of hydrogenate there was defined the sulphur content according to the State Standard $1437-75[7]$.

\section{Results and discussions}

The research of kinetics and thermodynamics of the process of hydrodesulphurization is necessary for improvement of the process-dependent parameters of hydrofining of the liquid products of hydrogenation. However at the same time there appear a number of methodological difficulties: first, it is practically impossible to identify a great number of individual compounds - the products of transformation of the organic mass of coal - therefore in practice they have to be grouped in accordance with some conventional physical and chemical qualities; second, the kinetics of the process in this case is formal and interpretation of its parameters from the point of view of the structural peculiarities of the source coal is quite a difficult task; third, for one and the same process different authors offer different kinetic models, the parameters of which are defined in complicated calculations, it makes them incomparable and non-general, and that complicates the performance of analysis of a model.

Taking into consideration the bibliographical data on kinetics of hydrodesulphurization there can be suggested the following scheme of hydrodesulphurization of the liquid products (hydrogenate) under moderate pressure of the hydrogen (Fig. 1).

The kinetic scheme of the process of hydrodesulphurization. According to the scheme indicated on the Figure 1 there is the following system of differential equations:

$$
\begin{gathered}
\frac{d\left[C_{1}\right]}{d \tau}=-\left(k_{1}+k_{2}-k_{3}\right) C_{1}+k_{4} C_{3} ; \\
\frac{d\left[C_{2}\right]}{d \tau}=k_{1} C_{1}+k_{5} C_{3} ; \\
\frac{d\left[C_{3}\right]}{d \tau}=k_{2} C_{1}-k_{5} C_{3} \\
\frac{d\left[C_{4}\right]}{d \tau}=k_{3} C_{1}-k_{6} C_{4}-k_{7} C_{4}
\end{gathered}
$$


where $k_{z}=k_{1}+k_{2}+k_{3}+k_{4}+k_{5}+k_{6}+k_{7} ; C_{1}, C_{2}, C_{3}, C_{4}$ are the mass fractions of the respective components $\left(C_{1}+C_{2}+C_{3}+C_{4}=1\right)$.

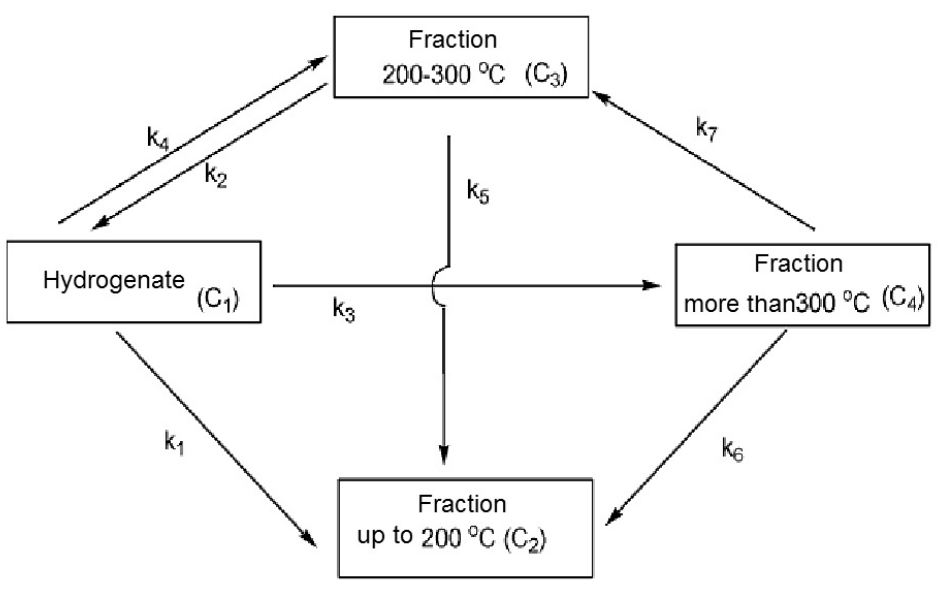

Figure 1. Kinetic scheme of the process of hydrodesulphurization of hydrogenate

The calculation of the system of equations was performed on PC IBM 486D4x0 with the usage of the special «Search» program [8-10]. The designed program makes it possible to calculate the kinetic dependences under the defined initial conditions and realize automated selection with the usage of the method of gradient of optimum values of constants of $k_{1}-k_{7}$ rates. Optimization of the constants of rates was realized provides there was a minimum of deviation squares between the experimental and calculated values of the mass fractions of the products of hydrodesulfurization. The constants of rate of hydrodesulphurization are $k_{1}=1.235, k_{2}=1.134, k_{3}=0.752, k_{4}=0.453, k_{5}=0.578, k_{6}=0.183, k_{7}=0.457$. Basing on analysis of the results of the rate constants there can be drawn the conclusion that the influence of the constants on the output of the products of the process of hydrodesulphurization is ambiguous. Thus, the output of the fraction under $200{ }^{\circ} \mathrm{C}$ is mainly determined by the value of $k_{1}$ rate constant. The output of the fraction of $200-300{ }^{\circ} \mathrm{C}$ decreases with the growth of the temperature and is mainly determined by the rate of reaction $k_{2}$. The constant of the rate of reverse reaction $k_{4}$ decreases with the growth of temperature.

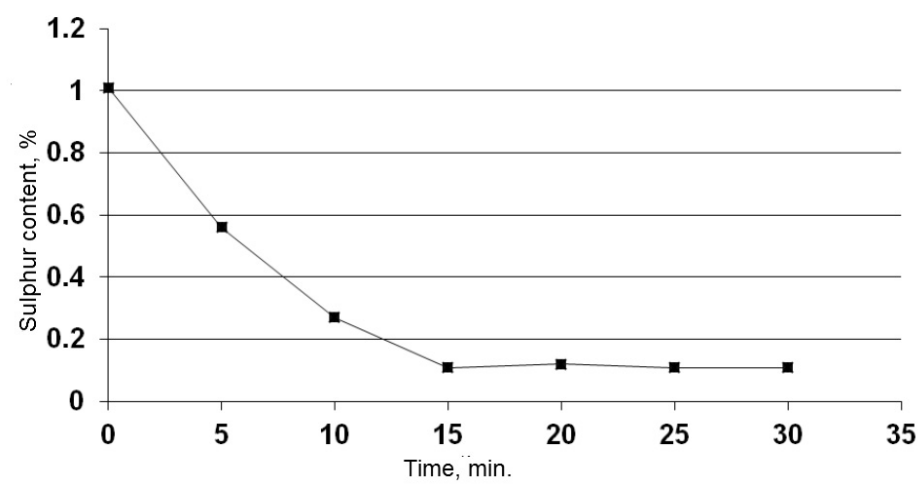

Figure 2. Kinetic data of the process of hydrodesulphurization of hydrogenate

On Figure 2 there is indicated the dependence of the sulphur content in hydrogenate on the time of the process of hydrodesulphurization. The analysis of the kinetic data of the process of hydrodesulphurization indicates that the optimal time of the process is 15-25 minutes, since there is observed the maximal output of the abovementioned fractions. The mentioned fractions contain sulphur in the following amounts:

Fraction under $200^{\circ} \mathrm{C}-0.043$ per cent (State Standard $-0.02-0.1$ per cent);

Fraction of $200-300^{\circ} \mathrm{C}-0.065$ per cent (State Standard $-0.2-1.0$ per cent);

The content of sulphur in the initial hydrogenate produced from the coal from Shubarkol Deposit amounts to 1.01 per cent. 
Basing on the experimental data of the research of the process of hydrodesulphurization of hydrogenate there was calculated the Gibbs energy $(\Delta G)$ using the formula:

$$
\begin{gathered}
G=-R T \ln K_{P} ; \\
K_{P}=k_{2} / k_{4} ; \\
\ln K_{P}=2.5033 ; K_{P}=0.918 ; \\
\Delta G=-5365.5 .
\end{gathered}
$$

The high value of ( $G$ (in absolute magnitude) indicates a high thermodynamic probability of performance of the process of hydrodesulphurization in this temperature range.

\title{
Conclusion
}

Thus, there is given the scheme of hydrodesulphurization of liquid products (hydrogenate), there are researched the kinetics and thermodynamics of the process of hydrodesulphurization in the presence of the catalyst of pyrite and natural zeolite. The calculated Gibbs energy in absolute magnitude indicates a high probability of the performance of the process of hydrodesulphurization. These data are necessary for improvement of the parameters of the process of hydrofining of the liquid products.

It is defined that the optimal time of the process of hydrodesulphurization is $15-25$ minutes. The indicated fractions contain sulphur in the following amounts: fraction under $200{ }^{\circ} \mathrm{C}-0.043$ per cent, and fraction of $200-300{ }^{\circ} \mathrm{C}-0.065$ per cent.

\section{References}

1 Юлин М.К. Гидрогенизация тиофена на цеолитных катализаторах / М.К. Юлин, Н.Ф. Мегед, С.В. Головченко, А.И. Межлумова, А.С. Арифулин // Химия твердого топлива. - 1988. - Т. 1. - С. 85-88.

2 Радченков Е.Д. Промышленные катализаторы гидрогенизационных процессов нефтепереработки / Е.Д. Радченков, Б.К. Нефедов, Р.Р. Алиев. - М.: Химия, 1987.

3 Сидельникова В.Г. Роль цеолитного компонента в улучшении каталитических, эксплуатационных и регенерационных свойств катализаторов гидроочистки / В.Г. Сидельникова, Р.Р. Алиев // Химия твердого топлива. — 1994. — Т. 4. C. $14-18$.

4 Ахметкаримова Ж.С. Теория и практика переработки тяжелого углеводородного сырья Центрального Казахстана / Ж.С. Ахметкаримова. - Караганда: Форма плюс, 2016.

5 Мейрамов М.Г. Гидрогенизация модельных соединений в присутствии железосодержащих катализаторов / М.Г. Мейрамов // Химия твердого топлива. — 2014. - Т. 2. - С. 50-55.

6 Breysse M., Portefaix J.J., Vrinat M. // J. Catalysis Today. — 1991. — Vol. 10, No. 1. — P. 489-505.

7 Малышев В.П. Равновесно-кинетический анализ химических процессов / В.П. Малышев, В.Г. Шкодин, - Алма-Ата: Гылым, 1990.

8 Шахтахтинский Т.Н. Методы оптимизации процессов химической технологии с программами для ЭВМ / Шахтахтинский Т.Н., Бахманов М.Ф., Кебалиев Г.И. — Баку: Эльм, 1985.

9 GOST 2117-99. Нефтепродукты. Метод определения фракционного состава.

10 GOST 1437-75. Нефтепродукты темные. Ускоренный метод определения серы.

\author{
А.Т. Ордабаева, Ж.С. Ахметкаримова, М.Г. Мейрамов, В.А. Хрупов, \\ Ж.Х. Мулдахметов, А.М. Дюсекенов, Ма Фэн Юнь
}

\section{Шұбаркөл көмір гидрогенизатының гидросульфирлеу үрдісінің термодинамикасы мен кинетикасы}

\begin{abstract}
Көмір мен мұнайды қайта өндеу кезіндегі отын компонентерінің құрамындағы күкірт қосылыстары МЖСТ-нің күкірт құрамы бойынша талаптарды қанағаттандырмайды. Күкірт соңғы өнімнің сапасына кері әсерін тигізіп қайта өндеуді қиындатады, сондықтан мұнай, көмір гидрогенизаттарын гидросульфирлеу маңызды болып табылады. Сұйық өнімдер (көмірсутектер) үшін күкіртті қосылыстар өте зиянды қоспа екені белгілі. Олар уытты, сұйық өнімдерге жағымсыз иіс береді, бензиннің антидетонационды қасиетіне кері әсерін тигізеді, металдардың коррозияға ұшырауын тудырады және ішкі жану қозғалтқыштың шайыр түзуіне септігін тигізеді. Сол себепті осы заттардың болуын тудыртпау қажет. Шұбаркөл кенорын көмірінен табиғи цеолит пен пирит катализаторының қатысуымен гидрогенизаттың гидросульфирлеу үрдісі зерттелді. Гидрогенизацияның сұйық өнімдерінің гидротазалағыш технологиялық сипаттамаларын жақсартуға болады, Гиббс энергиясы мен сұйық өнімдердің гидросульфирлеу үрдісінің жылдамдық константталары кинетикалық тепе-
\end{abstract}


теңдік тәсілмен есептелді. Гидросульфирлеу үрдісінің тиімді уақыты 15-25 мин екендігі көрсетілді. $200{ }^{\circ} \mathrm{C}$-дейінгі фракцияның құрамында күкірт мөлшері - 0,043\%, ал $200-300{ }^{\circ} \mathrm{C}$ аралығында $0,065 \%$, бұл жоғарыда келтірілген катализатор қатысында гидрогенизатты гидротазалау дәрежесінің жоғары екендігін көрсетті. $\Delta G$-дің жоғарғы мәні осы температуралық аралықта гидросульфирлеу үрдісінің термодинамикалық жүру мүмкіндігінің жоғары екендігін дәлелдеді. Бұл мәліметтер үрдісті жүргізудің ең қолайлы жағдайын анықтау бойынша ұсынысты жасауға қажет.

Кілт сөздер: гидродесульфуризациялау, гидрогенизат, кинетикалық талдау тепе-теңдігі.

\author{
А.Т. Ордабаева, Ж.С. Ахметкаримова, М.Г. Мейрамов, В.А. Хрупов, \\ Ж.Х. Мулдахметов, А.М. Дюсекенов, Ма Фэн Юнь
}

\title{
Кинетика и термодинамика процесса гидрообессеривания гидрогенизата шубаркольского угля
}

\begin{abstract}
При переработке углей, нефтей, содержащих соединения серы, получаемые топливные компоненты не удовлетворяют требованиям ГОСТов по содержанию серы. Сера отрицательно влияет на качество целевого продукта и затрудняет переработку, поэтому гидрообессеривание угольных гидрогенизатов, нефтей - важный этап перед их дальнейшей переработкой. Для жидких продуктов (углеводородов) сернистые соединения являются очень вредной примесью. Они токсичны, придают жидким продуктам неприятный запах, вредно отражаются на антидетонационных свойствах бензинов, способствуют смолообразованию в двигателях внутреннего сгорания и, главное, вызывают коррозию металлов. Поэтому присутствие этих веществ крайне нежелательно и недопустимо. Исследован процесс гидрообессеривания гидрогенизата из угля Шубаркольскоко месторождения в присутствии катализатора пирита и природного цеолита. Методом равновесно-кинетического анализа рассчитаны константы скорости процесса гидрообессеривания жидких продуктов и энергия Гиббса, которые необходимы для улучшения технологических параметров гидроочистки жидких продуктов гидрогенизации. Показано, что оптимальное время процесса гидрообессеривания 15-25 мин. Содержание серы во фракции до $200{ }^{\circ} \mathrm{C}-0,043 \%$, а во фракции $200-300{ }^{\circ} \mathrm{C}-0,065 \%$, что свидетельствует о высокой степени гидроочистки гидрогенизата в присутствии указанного выше катализатора. Высокое значение $\Delta G$ (по абсолютной величине) говорит о высокой термодинамической вероятности протекания процесса гидрообессеривания в данном температурном интервале. Эти данные необходимы для разработки рекомендаций по определению оптимальных условий проведения процесса.
\end{abstract}

Ключевые слова: гидродесульфуризация, гидрогенизация, равновесие кинетического анализа.

\section{References}

1 Yulin, M.K., Meged, N.F., Golovchenko, S.V., Mezhlumova, A.I., \& Arifulin, A.S. (1988). Gidrogenizatsiya tiofena na tseolitnyih katalilizatorah [Hydrogenation of thiophene on zeolite catalyst]. Himiya tverdogo topliva. - J. Chemistry of solid fuel, 1, 85-88 [in Russian].

2 Radchenkov, E.D., Nefedov, B.K., Aliev, R.R. (1987). Promyishlennyie katalizatoryi gidrogenizatsionnyih protsessov neftepererabotki [Industrial catalysts of hydrogenation refining processes]. Moscow: Khimiia [in Russian].

3 Sidelnikova, V.G., Aliev, R.R. (1994). Rol tseolitnogo komponenta v uluchshenii kataliticheskih, eksplutatsionnyih i regeneratsionnyih svoystv katalizatorov gidroochistki [The role of the zeolite component of the catalyst to be improved and the operational properties of the hydrotreating catalysts regenerable]. Himiya tverdogo topliva. - J. Solid Fuel Chemistry, 4, 14-18 [in Russian].

4 Akhmetkarimova, Zh.S. (2016). Teoriya i praktika pererabotki tyazhelogo uglevodorodnogo syiryaTsentralnogo Kazahstana [Theory and practice of processing of heavy hydrocarbonic rawmaterials of the Central Kazakhstan]. Karaganda: Form plus [in Russian].

5 Meiramov, M.G. (2014). Gidrogenizatsiya modelnyih soedineniy v prisutstvii zhelezosoderzhaschih katalizatorov [Hydrogenation of model compounds in the presence of iron-containing catalysts]. Himiya tverdogo topliva. - J. Chemistry of solid fuel, 2 , $50-55$ [in Russian].

6 Breysse, M., Portefaix, J.J., Vrinat, M. (1991). J. Catalysis Today, 10, 1, 489-505.

7 Malyshev, V.P., Shkodin, V.G. (1990). Ravnovestno-kineticheskiy analiz himicheskih protsessov [Equilibrium kinetic analysis of chemical processes]. Alma-Ata: Gylym [in Russian].

8 Shakhtakhtinsky, T.N., Bakhmanov, M.F., Kebaliev, G.I. (1985). Metodyi optimizatsii protsessov himicheskoy tehnologii s programmami dlya EVM [Methods of optimization processes of chemical technology with computer programs]. Baku, Elm [in Russian].

9 Nefteprodukty. Metod opredeleniya fraktsionnogo sostava [Petroleum products. The method for determining the fractional composition]. GOST 2117-99 [in Russian].

10 Nefteprodukty temnye. Uskorennyi metod opredeleniya sery [Petroleum products. Rapid method for the determination]. GOST 1437-75 [in Russian]. 